\title{
Economics of Fish Demands in Lagos State, Nigeria
}

\author{
J. O. Amao' ${ }^{1}$ I. B. Oluwatayo² and F. K. Osuntope ${ }^{3}$ \\ 1. Department of Agricultural Economics and Extension, Ladoke Akintola Uninversity of \\ Technology Ogbomoso, Oyo State, Nigeria \\ 2. Department of Agricultural Economics and Extension, University of Ado Ekiti, Nigeria \\ 3. Department of Agricultural Economics, University of Ibadan, Ibadan, Nigeria
}

KEYWORDS Fish. Consumers. Demand. Expenditure. Demographic Variables

\begin{abstract}
This study analysed the economics of fish demands in Lagos State, Nigeria. Primary data were collected from a total of 110 fish consumers using multistage sampling procedure. Data were collected on household consumption activities for 2002 consumption period. The data were analysed using descriptive statistics and regression analysis. The results showed that the average sampled consumers are literate with mean household size of 5. It was evident from the study that, the higher the income level of the respondents the higher the quantity of fish demanded and fish demand also increases as household size and age increases. The result of the regression analysis revealed that fish demand in the study area is income inelastic. It was also revealed that (income, substitute, household size and age) half of the variables positively influenced the monthly expenditure on fish, while the rest four variables (sex, marital status, occupation and education) influenced the monthly expenditure on fish negatively. However, age and education had significant relationship with monthly expenditure on fish.
\end{abstract}

\section{INTRODUCTION}

Fish and fish products are known worldwide as a very important diet because of their high nutritive quality and significance in improving human health. Fish which contributes $36.6 \mathrm{gm}$ per day of net protein utilization in Nigerian homes, is still below the recommended requirement by the world health organisation (WHO). The short fall is not because of the nonavailability of the resource but due to none maximization and sustainable utilization of available aquatic resources. Nigerian has over 12.5 million-hectare of inland water capable of producing over 350,000 metric tonnes of fish annually.

Fish plays a vital role in feeding the worlds population and contributing significantly to the dietary protein intake of hundreds of millions of the populace. On a global scale, almost 16 percent of total average intake of animal protein was attributable to fish in 1988 (FAO 1990). In the developing worlds, fish is a highly acceptable food that supplies as much as 40 percent of all animal protein available of the countries where fish is the main source of animal protein, 39 out of the top 40 are found in the developing world. Moreover, the poor spend proportionally more on fish than on meat or other sources of animal protein.

Over the past 15 years, however, fish has enjoyed an explosive increase in demand a demand that has also boosted its price. There is heightened awareness in the developed world of the nutritional and health benefit of fish products low in fat and calories and high in protein, vitamins, mineral and polyunsaturated fatty acids.

Increased attention to fish and fish products has caused prices to spiral with potentially serious consequences for consumers in the third world. While the bulk of fish harvested is still used for domestic consumption. Increased world demand for fish is placing pressure on developing countries to export fish to earn foreign exchange.

Omu (1986); in a study of factors affecting consumption found that consumption is an increasing function of income. He said that consumers will arrange consumption in such a way that the marginal utility derived from each commodity is proportional to price. Other factors that affect consumption are; the stock of past assets and expectations of prices rising.

Ajana (1999) indicated that relative small changes in food prices affect the ability of consumers to meet basic nutritional requirements. However, the impact of these changes on consumption differ among income groups. FAO's latest studies on future demand for and supply of fish and fishery products predicted a serieable increase in demand for fish. The majority of this increase will result from expected economic development, population 
growth and changes in food habits. Supply from capture fisheries is expected to remain constant, or even to decline (FAO, 2001). Indeed, fish supply from the capture fisheries in most countries is believed to have reached or be close to the maximum sustainable yield.

A research into the problem on nutrition reveals that many people in the developing countries of the world are undernourished at least one out of nine persons sampled (FAO, 1991). Despite all developmental programmes on food accessibility and availability carried out by the Nigerian government, hunger and malnutrition still exists in most part of the country. In a meeting of the African Regional Nutrition Strategy in 1993, Nigeria was included as one of the countries having the lowest daily per capita supplies of between 70-90 percent of nutrition requirements.

The major way of accessing protein malnutrition is by physical growth and body measurements, still wide spread in Nigeria affecting vulnerable groups. These include infants, pre school children, pregnant and lactating mothers and adults particularly from low income household.

The specific objectives are to:

(i) examine the socio-economic characteristics of the respondents.

(ii) determine the relationship between socioeconomic characteristics of fish consumers and their expenditure on fish.

(iii) estimate the household marginal propensity to consume fish in the study area.

\section{METHODOLOGY}

The study was carried out in Lagos metropolis. The State is approximately on $28^{\circ} 40^{\prime}$ East Longitude and 6020 North Latitude. Two local government areas covered in the State are Surulere and Badagry.

The respondents used were the fish consumers in the two local government areas. Primary data were collected through administration of questionnaire. Multistage sampling technique was employed in data collection. In this regard, the two local government areas were stratified into income levels, which may be either low, middle or high level. Using these strata, households were then sampled randomly. A total of 200 households were picked for sampling, 100 questionnaires were administered for each of the two local government areas of Surulere and Badagry. Out of these 200, questionnaires, 50 and 60 were returned and used for the analysis respectively.

The data collected for the study were analysed using descriptive statistics and multiple regression analysis. Each of the analytical framework is briefly discussed below.

The descriptive statistics used include mean, tabular presentation, frequencies and percentages followed by discussion of the tables.

The implicit function for the regression analysis is presented in equation (1)

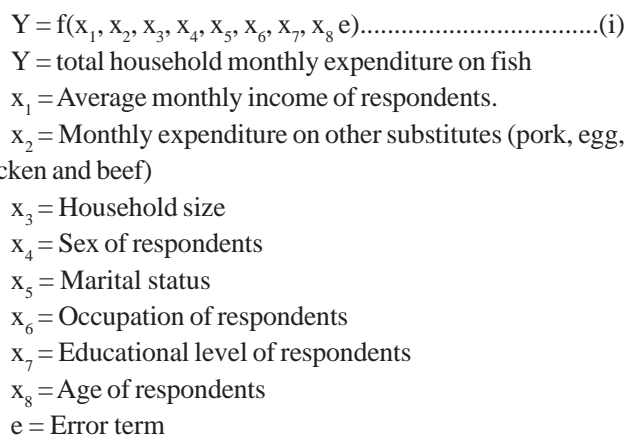

Functional Specification: The relationship between the endogenous and each of the exogenous variable were examined using 4 functional forms: linear, semi-log, Exponential and Double-log.

Linear: $\mathrm{Y}=\mathrm{b}_{0}+\mathrm{b}_{1} \mathrm{x}_{1}+\mathrm{b}_{2} \mathrm{x}_{2}+\mathrm{b}_{3} \mathrm{x}_{3}+\mathrm{b}_{4} \mathrm{x}_{4}+\mathrm{b}_{5} \mathrm{x}_{5}+\mathrm{b}_{6} \mathrm{x}_{6}+$

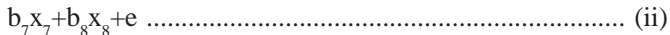

Semi-log: $\mathrm{Y}=\mathrm{b}_{0}+\mathrm{b}_{1} \log \mathrm{x}_{1}+\mathrm{b}_{2} \log \mathrm{x}_{2}+\mathrm{b}_{3} \log \mathrm{x}_{3}+\mathrm{b}_{4} \log$ $\mathrm{x}_{4}+\mathrm{b}_{5} \log \mathrm{x}_{5}+\mathrm{b}_{6} \log \mathrm{x}_{6}+\mathrm{b}_{7} \log \mathrm{x}_{7}+\mathrm{b}_{8} \log \mathrm{x}_{8}+\log \mathrm{e}$.............. (iii)

Exponential: $\log \mathrm{Y}=\mathrm{b}_{0}+\mathrm{b}_{1} \mathrm{x}_{1}+\mathrm{b}_{2} \mathrm{x}_{2}+\mathrm{b}_{3} \mathrm{x}_{3}+$

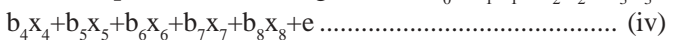

Double-log: $\log \mathrm{Y}=\mathrm{b}_{0}+\mathrm{b}_{1} \log \mathrm{x}_{1}+\mathrm{b}_{2} \log \mathrm{x}_{2}+\mathrm{b}_{3} \log \mathrm{x}_{3}+\mathrm{b}_{4}$ $\log \mathrm{x}_{4}+\mathrm{b}_{5} \log \mathrm{x}_{5}+\mathrm{b}_{6} \log \mathrm{x}_{6}+\mathrm{b}_{7} \log \mathrm{x}_{7}+\mathrm{b}_{8} \log \mathrm{x}_{8}+\log \mathrm{e} \ldots . . .(\mathrm{v})$

The lead equation called the best linear unbiased estimate (BLUE) functional form was then chosen based on statistical significance, the economic theory that support consumption function concept and the apriori expectation of the variables.

Apriori Expectation: Some of the variables $\left(\mathrm{x}_{1}+\mathrm{x}_{3}+\mathrm{x}_{6}+\mathrm{x}_{7}\right.$ and $\left.\mathrm{x}_{8}\right)$ are expected to positively influence total household monthly expenditure on fish. While the remaining three $\left(\mathrm{x}_{2}, \mathrm{x}_{4}\right.$ and $\mathrm{x}_{5}$ ) are expected to have negative impact on total household monthly expenditure on fish. Though, linear functional form was finally chosen on the basis of the apriori expectation viz; signs and 
magnitude of the independent variables, economic considerations, the coefficient of determination and magnitude of the error term as well as statistical significance of the coefficient of independent variables. (Olayemi and Olayide 1981). The final equation is therefore presented in equation (vi).

$$
\mathrm{Y}=\mathrm{b}_{0}+\mathrm{b}_{1} \mathrm{x}_{1}+\mathrm{b}_{2} \mathrm{x}_{2}+\mathrm{b}_{3} \mathrm{x}_{3}+\mathrm{b}_{4} \mathrm{x}_{4}+\mathrm{b}_{5} \mathrm{x}_{5}+\mathrm{b}_{6} \mathrm{x}_{6}+\mathrm{b}_{7} \mathrm{x}_{7}+\mathrm{b}_{8} \mathrm{x}_{8}+\mathrm{e}
$$

Elasticity and marginal propensity to consume (MPC)

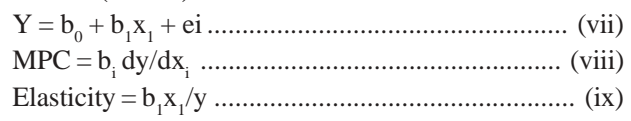

\section{RESULT AND DISCUSSION}

The first subsection is devoted to socioeconomic characteristics of the respondents while subsection two is devoted to the relationship between socio-economic characteristics of fish consumers and there expenditure on fish. The last subsection examines the household marginal propensity to consume fish in the study area.

Table 1 showed the distribution of respondents according to their personal characteristics from the study area. Both the frequency and the percentage distributions were shown in the table. The mean age was found to be 40.5 years indicating that they are in their active and productive age. The quantity and quality of protein requirement of individual is sometimes determined by age of the members of the household. Because, food consumption pattern generally follows the body compositions. The study showed that the area was dominated by married people an indication of the fact that many of the respondents are stable and consume more fish. However, one may say that the area is dominated by literate people with the evidence that consumption of fish has to do with knowing the importance of protein and the best source of it through education. It was also gathered that to each household averagely they were five in the house, which is an indication of an increase expenditure on fish and invariably more demand for fish.

Furthermore, about $59 \%$ of the respondents indicated that civil service is their main occupation. Also, many consumers were female about $66 \%$ because women are the food planners of the family in most cases and they are the major ones interviewed for the study. The male respondents are men who are either barchellor, divorced or separated from their spouse making them food planners. And it was also gathered that majority of the respondents in the study area were earning an average income less than $\mathrm{N} 10,000$ while non is earning an average income above $\$ 40,000$. Income level plays a vital role in the nutritional value of individual. People tend to demand more or change their taste over time as their income level changes.

Table 1: Distribution of respondents according to their socio-economic characteristics in Lagos State.

\begin{tabular}{|c|c|c|}
\hline $\begin{array}{l}\text { Socio-economic } \\
\text { characteristics }\end{array}$ & Frequencies & Percentage \\
\hline \multicolumn{3}{|l|}{ Age } \\
\hline $21-30$ & 10 & 9.09 \\
\hline $31-40$ & 45 & 40.91 \\
\hline $41-50$ & 44 & 40.00 \\
\hline $51-60$ & 11 & 10.00 \\
\hline Total & 110 & 100.00 \\
\hline \multicolumn{3}{|l|}{ Mean age -40.5} \\
\hline \multicolumn{3}{|l|}{ Marital status } \\
\hline Single & 23 & 20.91 \\
\hline Married & 78 & 70.91 \\
\hline Divorced & 6 & 5.45 \\
\hline Widowed & 3 & 2.73 \\
\hline Total & 110 & 100.00 \\
\hline \multicolumn{3}{|l|}{ Education } \\
\hline None & 1 & 0.90 \\
\hline Primary & 9 & 8.20 \\
\hline Secondary & 40 & 36.40 \\
\hline Tertiary & 60 & 54.50 \\
\hline Total & 110 & 100.00 \\
\hline \multicolumn{3}{|l|}{ Household size } \\
\hline $1-3$ & 27 & 24.50 \\
\hline $4-6$ & 64 & 58.20 \\
\hline $7-9$ & 19 & 17.30 \\
\hline Total & 110 & 100.00 \\
\hline \multirow{2}{*}{\multicolumn{3}{|c|}{$\begin{array}{l}\text { Occupation } \\
\text { Octa -J }\end{array}$}} \\
\hline & & \\
\hline Farming & 3 & 2.73 \\
\hline Civil servant & 65 & 59.09 \\
\hline Artisan & 7 & 6.36 \\
\hline Others & 35 & 31.82 \\
\hline Total & 110 & 100.00 \\
\hline \multicolumn{3}{|l|}{ Gender } \\
\hline Male & 37 & 33.64 \\
\hline Female & 73 & 66.36 \\
\hline Total & 110 & 100.00 \\
\hline \multicolumn{3}{|l|}{ Income level $(N)$} \\
\hline$<10,000$ & 51 & 46.36 \\
\hline $10000-20000$ & 28 & 25.45 \\
\hline $20001-30000$ & 22 & 20.00 \\
\hline $30001-40000$ & 09 & 8.18 \\
\hline$>40000$ & - & - \\
\hline Total & 110 & 100.00 \\
\hline
\end{tabular}

Source: Field Survey, 2002 
The analysis of monthly expenditure on fish by income level of respondents in the study revealed a lot about fish demand in the study area. Table 2 further shows that average monthly expenditure on fish by respondents increase as income increases. This is an indication that at higher income better and expenditure foods such as animal protein would be consumed but the percentage of monthly expenditure by income levels, however, decreases with increase in income. This confirms Engels law.

Table 2 also showed that, the average monthly expenditure on substitute by income level less than ten thousand naria $<\mathbb{N} 10000$ respondents was $¥ 1671.57$. The income level of (10000-20000)A respondents was $\$ 2275$. The respondents with income level of (20001,30000)※. Spent $¥ 2686.36$ on substitute per month while respondents with income level between (30001-40000)A spent $\$ 3366.67$. This showed that the average monthly expenditure on substitute increase with income. However, the percentage of income spent on substitute decrease with increase in income which agree with Engel's law which states that "the proportion of income spent on food decline as income increases"

Table 3 shows the average monthly expenditure on fish by socio-economic characteristics preference for fish types in the study area. It was evident from the table that age, educational level and household size had direct relationship with average expenditure on fish, occupation and marital status had no definite pattern with average expenditure on fish while sex of the respondents had a definite pattern with the average expenditure on fish of female respondents greater than that of male.

Furthermore, from table 3, it was clearly shown that, large proportion of respondents (58) accounted for about 53 percent of the sampled respondents preferred cat fish to any other type of fish, about 22 percent preferred tilapia, while 18 percent and 7 percent preferred Mackerel and Stock fish respectively. This showed that, majority of the respondents in the study area preferred fresh fish to Marin fish or iced fish.

Table 4 showed average monthly expenditure on fish and substitute by income levels and it was revealed that the average monthly expenditure on substitute and fish increase as income increases. It was also revealed from the table that the respondents with income less than $\AA 10,000.00$ and income between (10,00020,000)A levels spent more on substitute than fish. This might be due to the relative cheapness of the substitute. But, for respondents with income levels of between (20001-30000) $\mathrm{N}$ and (30001-40000) $\mathrm{N}$, the expenditure on fish is higher than that of its substitute. This is because as consumers become more affluent, there is a tendency to consume more fish and less of its

Table 2: Respondents monthly expenditure on fish and substitute by income level

\begin{tabular}{|c|c|c|c|c|c|c|}
\hline \multirow[t]{6}{*}{$\begin{array}{l}\text { Expenditure } \\
\text { on fish }\end{array}$} & $\begin{array}{c}\text { Income } \\
\text { level } \\
\text { (N) }\end{array}$ & Frequency & $\begin{array}{l}\text { Average } \\
\text { monthly } \\
\text { income } \\
\text { (A) }\end{array}$ & $\begin{array}{l}\text { Total monthly } \\
\text { income }\end{array}$ & $\begin{array}{l}\text { Average } \\
\text { monthly } \\
\text { expenditure } \\
\text { on fish }(\mathrm{A})\end{array}$ & $\begin{array}{c}\text { Percentage of } \\
\text { income spent } \\
\text { on fish }\end{array}$ \\
\hline & $<10000$ & 51 & 8500 & 62700 & 1229.41 & 12.29 \\
\hline & $10000-20000$ & 28 & 16635.71 & 54650 & 1951.79 & 11.73 \\
\hline & $20001-30000$ & 22 & 23663.64 & 60400 & 2745.46 & 11.60 \\
\hline & $30001-40000>$ & 09 & 37388.89 & 33100 & 3677.78 & 9.84 \\
\hline & above 40000 & - & - & - & - & - \\
\hline \multirow[t]{6}{*}{$\begin{array}{l}\text { Expenditure } \\
\text { on fish }\end{array}$} & $\begin{array}{c}\text { Income } \\
\text { level } \\
\text { (स) }\end{array}$ & Frequency & $\begin{array}{l}\text { Average } \\
\text { monthly } \\
\text { income } \\
\text { (A) }\end{array}$ & $\begin{array}{l}\text { Total monthly } \\
\text { income } \\
\text { (N) }\end{array}$ & $\begin{array}{c}\text { Average } \\
\text { monthly } \\
\text { expenditure } \\
\text { on substitute } \\
\text { (N) }\end{array}$ & $\begin{array}{c}\text { Percentage of } \\
\text { income spent } \\
\text { on } \\
\text { subtitute }\end{array}$ \\
\hline & $<10000$ & 51 & 8500 & 85250 & 1671.57 & 16.75 \\
\hline & $10000-20000$ & 28 & 16635.71 & 367000 & 13107.14 & 13.68 \\
\hline & $20001-30000$ & 22 & 23663.64 & 59100 & 2686.36 & 11.35 \\
\hline & $30001-40000$ & 09 & 37388.89 & 30300 & 3366.67 & 9.00 \\
\hline & $>40000$ & - & - & - & $\therefore$ & - \\
\hline
\end{tabular}

Source: Field Survey, 2002. 
Table 3: Average monthly expenditure on fish by socioeconomic characteristics and preference for fish types in Lagos State

\begin{tabular}{|c|c|c|c|c|}
\hline $\begin{array}{l}\text { Socio- } \\
\text { economic } \\
\text { characteristics }\end{array}$ & $\begin{array}{l}\text { Fre- } \\
\text { que- } \\
\text { ncy }\end{array}$ & $\begin{array}{c}\text { Total } \\
\text { monthly } \\
\text { expen- } \\
\text { diture } \\
\text { of fish }\end{array}$ & $\begin{array}{c}\text { Average } \\
\text { monthly } \\
\text { expen- } \\
\text { diture } \\
\text { on fish }\end{array}$ & $\begin{array}{c}\text { Percen- } \\
\text { tage } \\
\text { of monthly } \\
\text { expen- } \\
\text { diture } \\
\text { on fish }\end{array}$ \\
\hline \multicolumn{5}{|l|}{ Age } \\
\hline $21-30$ & 10 & 19900 & 1900.00 & 23.68 \\
\hline $31-40$ & 45 & 90850 & 2108.89 & 24.02 \\
\hline $41-50$ & 44 & 95000 & 2159.09 & 25.69 \\
\hline $51-60$ & 11 & 24600 & 2236.36 & 26.61 \\
\hline \multicolumn{5}{|l|}{ Level of Education } \\
\hline No formal education & 01 & 1800 & 1800.00 & 23.78 \\
\hline Primary education & 09 & 16200 & 1860.00 & 23.78 \\
\hline Secondary education & n 40 & 5000 & 1875.00 & 24.77 \\
\hline Tertiary education & 60 & 125650 & 2094.17 & 27.67 \\
\hline \multicolumn{5}{|l|}{ Household Size } \\
\hline $1-3$ & 27 & 36500 & 1351.85 & 26.56 \\
\hline $4-6$ & 64 & 87000 & 1359.38 & 26.71 \\
\hline $7-9$ & 19 & 45200 & 2378.94 & 46.73 \\
\hline \multicolumn{5}{|l|}{ Occupation } \\
\hline Farming & 3 & 4500 & 1500.00 & 25.27 \\
\hline Civil servant & 63 & 91050 & 1445.24 & 24.35 \\
\hline Artisans & 6 & 9500 & 1583.33 & 26.67 \\
\hline Others & 38 & 53500 & 1407.89 & 23.71 \\
\hline \multicolumn{5}{|l|}{ Marital Status } \\
\hline Married & 23 & 42900 & 1865.22 & 27.32 \\
\hline Single & 78 & 160200 & 2053.85 & 30.08 \\
\hline Divorced & 6 & 7850 & 1308.33 & 19.16 \\
\hline Widowed & 3 & 4800 & 1600.00 & 23.44 \\
\hline \multicolumn{5}{|l|}{ Sex } \\
\hline Male & 37 & 27700 & 748.65 & 27.63 \\
\hline Female & 73 & 143150 & 1960.96 & 72.37 \\
\hline Fish types & \multicolumn{2}{|c|}{ Frequency } & \multicolumn{2}{|c|}{$\begin{array}{c}\text { Percentage of } \\
\text { distribution }\end{array}$} \\
\hline Cat fish & \multicolumn{2}{|l|}{58} & \multicolumn{2}{|c|}{52.73} \\
\hline Tilapia & \multicolumn{2}{|l|}{24} & \multicolumn{2}{|c|}{21.82} \\
\hline Mackerel & \multicolumn{2}{|l|}{20} & \multicolumn{2}{|c|}{18.18} \\
\hline Stock fish & \multicolumn{2}{|l|}{8} & \multicolumn{2}{|c|}{7.27} \\
\hline
\end{tabular}

Source: Field Survey, 2002

Table 4: Average monthly expenditure on fish and its substitute by income levels

\begin{tabular}{|c|c|c|c|c|c|}
\hline $\begin{array}{l}\text { Income } \\
\text { level }\end{array}$ & $\begin{array}{l}\text { Freq- } \\
\text { uency }\end{array}$ & $\begin{array}{c}\text { Average } \\
\text { monthly } \\
\text { expen- } \\
\text { diture } \\
\text { on sub- } \\
\text { stitute }\end{array}$ & $\begin{array}{c}\text { Average } \\
\text { monthly } \\
\text { expen- } \\
\text { diture } \\
\text { on fish }\end{array}$ & $\begin{array}{l}\text { Percen- } \\
\text { tage } \\
\text { of } \\
\text { income } \\
\text { spent on } \\
\text { sub- } \\
\text { stitute }\end{array}$ & $\begin{array}{l}\text { Percen- } \\
\text { tage } \\
\text { of } \\
\text { income } \\
\text { spent } \\
\text { on } \\
\text { fish }\end{array}$ \\
\hline$<10000$ & 51 & 1671.57 & 1229.41 & 16.75 & 12.29 \\
\hline $10000-2$ & $\begin{array}{ll}0 & 28\end{array}$ & 2275 & 1951.7 & 13.68 & 11.73 \\
\hline $20001-30000$ & $\begin{array}{ll}0 & 22\end{array}$ & 268.36 & 2745 & 11.35 & 11.60 \\
\hline $30001-40000$ & 9 & 3366.67 & 3677.78 & 9.00 & 9.84 \\
\hline$>40000$ & - & 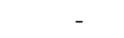 & 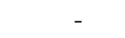 & - & . \\
\hline
\end{tabular}

Source: Field Survey, 2002 substitutes like egg, beef, pork etc.

Analysis of Regression Result: Olayemi and Olayide (1981) indicated that choice of appropriate functional forms may be based on a apriori expectation, an expectation which is in turn guided by economic theory. In this regard polynomials and linear functions are most common for consumption expenditure studies. Based on the statistical significance of the coefficients and the economic theory that support consumption expenditure concept, the linear function was chosen as the lead equation. The result is presented in table 5 .

The coefficient of multiple determination $\left(\mathrm{R}^{2}\right)$ was found to be $13.42 \%$ and was statistically significant at $5 \%$ level with respect to education and age. This implies that the level of education and the age of respondent had a significant influence on the demand for fish in the study area. This is an indication that 13 percent of the variation in the value of monthly expenditure on fish by the consumers is explained by the explanatory variables-income, monthly expenditure on substitute, household size, sex of respondents, marital status, occupation of respondents, educational level, and age. The remaining $87 \%$ not explained is attributed to other variables not included in the model.

From the regression result above, four regression coefficients were positively signed

Table 5: Regression results of fish demands in Lagos Metropolis

\begin{tabular}{lrrr}
\hline Predictor & $\begin{array}{c}\text { Estimated } \\
\text { parameter }\end{array}$ & $\begin{array}{c}\text { Standard } \\
\text { error }\end{array}$ & t-ratio \\
\hline Constant & 619.3436 & 316.1953 & 1.96 \\
$\mathrm{X}_{1}$ & 0.0006 & 0.0072 & 0.08 \\
$\mathrm{X}_{2}$ & 0.0526 & 0.0412 & 1.28 \\
$\mathrm{x}_{3}$ & 24.7836 & 30.2384 & 0.82 \\
$\mathrm{x}_{4}$ & -143.2720 & 116.7522 & -1.23 \\
$\mathrm{X}_{5}$ & -89.3056 & 135.9680 & -0.66 \\
$\mathrm{x}_{6}$ & -137.8172 & 185.2626 & -0.74 \\
$\mathrm{x}_{7}$ & $-441.9728^{*}$ & 189.4177 & -2.33 \\
$\mathrm{x}_{8}$ & $16.7417^{*}$ & 7.8619 & 2.13 \\
\hline
\end{tabular}

Source: Field Survey, 2002

* significant at $5 \%$ level

The regression equation is:

$$
\begin{aligned}
& \mathrm{Y}=619.3436+0.0006 \mathrm{x}_{1}+0.0526 \mathrm{x}_{2}+24.7836 \mathrm{x}_{3} \\
& \begin{array}{llll}
(316.1953) & (0.0072) & (0.0412)^{2} & (30.2384)
\end{array} \\
& -143.2720 \mathrm{x}_{4}-89.3056 \mathrm{x}_{5}-137.8172 \mathrm{x}_{6} \\
& (116.7522)(135.9680) \quad(185.2626) \\
& -441.9728 \mathrm{x}_{7}+16.7417 \mathrm{x} \\
& \text { (189.4177) (7.8619) }
\end{aligned}
$$

Figures in parentheses represent the standard error. 
which is a deviation from the a priori expectation while the rest four were negatively signed (i.e sex, marital status, occupation and educational level) which is also a deviation from the apriori expectation. Three variables were not confirmed with the apriori expectation and they are (monthly expenditure on substitute from positive to negative, occupation and educational level of respondents from positive to negative). All other regression coefficients were in confimmity with apriori expectation.

The coefficient of income, though not significant at any level but positively signed implies that it has a direct relationship on the fish consumed. Despite its insignificance, it is normal that people will prefer taking fish or increase their consumption of it, when there is increase in income.Both expenditure on substitute and family size variables are also positive but not significant showing that both have direct relationship with consumption. This implied that an increase in expenditure on substitute will cause an increase on fish consumption i.e consumer will stick to fish when its substitute for protein increases and at the same time an increase in family size will cause an increase in fish consumption.

The coefficient of age is positive and also significant at 5\% level. It has direct relationship with fish consumption. Sex, marital status, occupation and education had no direct relationship with the consumption of fish, but education is significant at 5\% level, which showed a relevant variable in fish consumption.

Elasticity and Marginal Propensity to Consume: This result led to computation of marginal propensity to consume with respect to income and income elasticity.

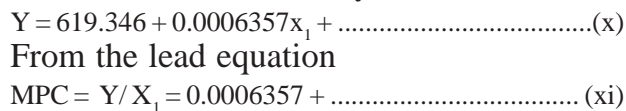

From this equation, MPC was calculated to be 13.69 with respect to income, which implies that a unit increase in income will make the consumer to increase their monthly expenditure on fish by $\mathrm{N} 13.69$.

Income Elasticity: The income elasticity is calculated thus:

$\mathrm{Ex}_{1}($ elasticity of income $)=\mathrm{Y} / \mathrm{x}_{1} \cdot \mathrm{x}_{1} / \mathrm{Y} \ldots \ldots \ldots \ldots \ldots \ldots . . . . . . . .(\mathrm{xii})$

$\mathrm{Y} / \mathrm{X}_{1}=0.0006357 \ldots \ldots \ldots \ldots \ldots \ldots \ldots \ldots \ldots \ldots \ldots \ldots \ldots \ldots \ldots . . . . . .(x i i i)$

$\mathrm{Ex}_{1}=(0.0006357) \mathrm{x}_{1} / \mathrm{Y} \ldots \ldots \ldots \ldots \ldots \ldots \ldots \ldots \ldots \ldots \ldots \ldots \ldots \ldots \ldots . . .(\mathrm{xiv})$

From equation (xiv), income elasticity was calculated to be 0.009 . From the computed elas- ticity, fish demand expenditure is income inelastic, since the value obtained was less than one indicating fish to be a necessity in the study area.

\section{CONCLUSION AND RECOMMENDATION}

The study examined fish demand in Lagos metropolis with a view of finding the trends in fish consumption and consumers preference for fish types/species. The study showed that income, education and age are major determinant of consumer demand for fresh fish, while factors such as age, familysize, marital status, substitute, sex are secondary determinants. The study also showed that high income earners preferred fresh fish to its substitute.

On the basis of the findings of the study, the following recommendations are made for the improvement in the fish demand, motivation of fish producers and for policy making.

Fresh fish, although available will require government intervention in its production, marketing and consumption in the following areas.

(I) Efforts should be made in increasing capital investment in the fishery subsector.

(ii) Since it was discovered that many people preferred fresh fish to frozen fish, effort should be made to discourage importation of frozen fish by encouraging the local fish farmers through incentives.

(iii) Grants, loans and subsidies should be given to fish farmers and marketers to enable them purchase modern equipments in order to increase supply.

(iv) Private individuals and corporate bodies should be encouraged to venture into fish production.

\section{REFERENCES}

Ajana A. M.: Overview of highlight and problems of fisheries extension in Nigeria. Paper presented at NIOMER during a workshop on "Improvement of Fisheries Extension in Nigeria. pp.22 (1999):.

FAO: Commodity Review and Outlook (1990-1991) (1990).

FAO: Fish for Food and Development. FAO Annual Publication, Rome (1991).

FAO: Fisheries Technical paper no $480 / 1$ promotion of sustainable commercial Aquaculture in sub-Saharan Africa vol. 1 Policy Framework (2001).

Olayemi J. K. and Olayide S. O.: Elements of Applied Econometrics Lesshyraden Nigeria Ltd. (1981).

Omu J. U.: Economics: an African Perspectives. John West Publication Ltd Nigeria (1986). 